8 Jacobson B. Beating the ladykillers-women and smoking. London: Gollanz, 1988

World Health Organisation Europe. It can be done-a smoke free Europe. Copenhagen: WHO, 1990.

10 Davis RM. Current trends in cigarette advertising and marketing. $N$ Engl f Med 1987;316:725-32.

11 Earnster VL. Mixed messages for women: a social history of cigarette smoking and advertising. NY State $\mathcal{f}$ Med 1985;85:335-40.

12 Amos A. How women are targeted by the tobacco industry. World Health Forum 1990;11:416-22.

13 Targeting the female smoker. Tobacco Reporter 1983 April:44-5.

14 Rogers D. Editorial. Tobacco Reporter 1987 Feb:8.

15 Jacobson B, Amos A. When smoke gets in your eyes-cigarette advertising policy and coverage of smoking and health in women's magazines 1985. London: BMA, 1985 .

16 Amos A, Jacobson B, White PC. Cigarette advertising policy and coverage of smoking and health in British women's magazines. Lancet 1991;337:93-6.

17 JICNARS. National readership survey. July 1988 to fune 1989. London: JICNARS, 1989.

18 Amos A. Young people, tobacco and 1992. Health Education foumal 1991;50:26-30.

19 Lock S. If preventable, why not? BMf 1990;301:1405-6.

20 Amos A, Bostock B. Putting women in the picture: cigarette advertising policy and coverage of smoking and health in women's magazines in Europe. London: BMA, 1991 .
21 Aitken PP, Leathar DS, O'Hagan FJ, Squair SI. Children's awareness of cigarette advertisements and brand imagery. Br $\mathcal{F}$ Addict 1987;82:615-22.

22 Charlton A. Children's advertisement awareness related to their views on smoking. Health Education fournal 1986;45:75-8.

23 Chapman S, Fitzgerald B. Brand preference and advertising recall in adolescent smokers. Am $\mathcal{F}$ Public Health 1982;72:491-4.

24 Aitken PP, Eadie DR. Reinforcing effects of cigarette advertising on under age smoking. Br $\mathcal{F}$ Addict 1990;85:399-412.

25 Aitken PP, Eadie DR, Hastings GB, Haywood AJ. Predisposing effects of cigarette advertising on children's intention to smoke when older. Br f Addict 1991;86:383-90.

26 Toxic Substances Board. Health or tobacco. Wellington: New Zealand Department of Health, 1989.

27 Warner KE. Cigarette advertising and media coverage of smoking and health. N Engl F Med 1985;312:384-8.

28 Warner KE, Goldenhar L, McLaughlin C. The economics of cigarette advertising: impacts on magazines' revenues and editorial practice regarding coverage of smoking and health. Proceedings of the seventh world conference on tobacco and health, 1990. Perth: Health Department of Western Australia, 1990:765-7.

29 Commission of the European Communities. Europe against cancer survey: Europeans and the European code against cancer. Brussels: European Commission, 1987

(Accepted 30 August 1991)
Centre of Russian and East European Studies, University College of Swansea, Swansea SA2 8PP

Michael Ryan, PHD, lecturer in politics and Russian studies

BMF 1992;304:101-3

\title{
Russian report: doctors and health service reform
}

\author{
Michael Ryan
}

Even before the "second Russian revolution" of August 1991 , governments of the republics were abandoning a range of institutional arrangements in response to the perceived needs and wishes of their electorates. This article will look at one example provided by a vote of the Russian Federation's Supreme Soviet (that is, the legislature) which took place towards the end of June. By approving the draft law entitled Concerning Medical Insurance of the Population deputies came down in favour of a scheme intended to make truly fundamental changes in the financing and organisation of health care.

Without the discipline formerly imposed by the Communist party, voting was not a rubber stamp affair but a genuine record of opinion among directly elected representatives in what is now a multiparty democracy. Their historic decision to terminate a state provided system which had virtually lost its legitimacy was exceptionally significant for a further reason. As this article shows, members of the profession most closely concerned had influenced the outcome with independent contributions to the processes of policy making and opinion building. In saying that I do not imply that a medical cabal had engaged in what Bernard Shaw might have denounced as a conspiracy against the laity, for the political propriety of the doctors' activity seems unchallengeable throughout the period of the reform's gestation, which started no later than September 1990, when deputies of the republic's Supreme Soviet appointed a new minister of health. The man whom they chose, Dr Vyacheslav Kalinin, made it clear that he was committed to the introduction of what the Russians call "insurance medicine."

Apparently, Dr Kalinin was able to provide an especially useful policy input since he moved from the USSR Health Ministry, where he had a hand in shaping the draft law entitled The Principles of Legislation of the USSR and Union Republics on the Financing of Health Care (A Telyukov, personal communication). I cannot establish whether the republican ministry had been working on its own plans before the advent of the new minister but, at the level of the legislature, the committee for health protection, social security, and physical culture of the Russian Supreme Soviet is known to have given initial consideration to its own text of a law at the end of October 1990. Deputies had before them a draft prepared within the health ministry and a similar one by an "initiative group" headed by a deputy who was a medical administrator. ${ }^{2}$

Doctors who were members of the committee could have been in no doubt as to the progressive deterioration of the existing health service and of health indicators for their republic. During the months which followed they and other doctors who supported the reform evidently considered themselves obliged to publicise the dismal facts with vehemence-even to the extent of evoking an apocalyptic vision of the future.

\section{Sounding the tocsin}

In the first free elections to the republic's Supreme Soviet, voters had returned a sizable total of 97 doctors as their chosen representatives (that is, deputies). By December 1990 most of these doctors decided that, given the now potentially catastrophic state of the nation's health, they should issue a public statement in form of an appeal to the entire body of deputies who had been convened for a special congress. One alarmist passage in this statement reads as follows:

The low expectation of life, especially among men, the high mortality, including infant mortality, the increase in crime, accidents, alcoholism, drug addiction, prostitution, AIDS, psychiatric ill-health, and the grave ecological situation is changing the nation's genetic stock for the worse and threatens our people with degeneration. Today as many as $75 \%$ of school-children suffer from diseases.... With the reduction in the number of rural inhabitants, the countryside is becoming more obviously "a reservation" of the sick and the elderly.

A subordinate point deserving notice is that the medical deputies also drew attention to negative consequences of the government's reforms of prices for goods and services. All part of the transition to a market driven economy, these reforms had the effect of seriously compounding the complex of problems which had long beset this badly neglected and chronically inefficient sector. Thus the acquisition of medical technology, which was always difficult, had now fallen by $50 \%$, the traditionally inadequate supply of pharmaceutical products had shrunk to a pitiful $19 \%$ of demand, and hospitals were struggling to cope with sharp rises in the costs of heating, lighting, and food for patients.

Having seen provisional figures in the government's budget for 1991, the doctors considered that "the residual principle" continued to determine the level of health service funding. On the basis of their experience 
and calculations, they stated, only some $50-60 \%$ of the necessary funds were made available. It seems consistent with the calculations that they should then have insisted on a commitment for 1991 of a sum "not less than $6 \%$ of the national product." For the same period they also demanded freely convertible currency to the sum of 2.5 billion roubles to buy medicines from abroad and, additionally, 445 million roubles to import medical equipment, apparatus, and instruments.

At the conclusion of their appeal the medical deputies addressed a separate theme: they considered it their civic duty to alert congress to "the very high level of social tension in our professional sphere." More concretely, they referred to the growing strength of the strike movement among health care staff and its potential for harm to the entire community. ${ }^{3}$ The leaders of Russia were soon to discover that they could no longer rely on the passivity of the medical and pharmaceutical workforce.

\section{No alternative}

Early in December "coordinating and strike committees of health service employees" held a conference which considered an ultimatum. In a decision of extraordinary significance for group identity they agreed to initiate a republic wide strike unless the government took decisive action to tackle the crisis situation. The employees' union had received no response to various appeals which it had previously made to the legislature and executive (including Boris Yeltsin); now it fixed on 1 January 1991 as its deadline. On 11 January the newspaper Meditsinskaya Gazeta carried an open letter, the publication of which was intended to signify the start of activity which would culminate in a strike.

An eight point list of demands set out in the letter may be deemed to summarise and synthesise the views of the majority as to what should be done. The first point repeated the medical deputies' call for not less than $6 \%$ of national wealth - or 28 billion roubles - to be allocated to the health service. The second called for the salaries of employees in this sector to to be raised to the average figure for the economy. (Earlier the letter noted that earnings in the sector were $43 \%$ lower than the average-even after changes brought in during 1990.) Also demanded was the introduction of a new concept whereby remuneration would reflect the actual cost of the services rendered, and a "contract form of payment for work." Regarding fundamental structural changes, on which it would formerly have never pronounced, the health service employees' union demanded two things. One was a partial privatisation of health service units, among them pharmacies, and enterprises which made pharmaceutical products, medical supplies, and medical technology. Acceptance of an equally massive discontinuity was implied in the demand for a system of medical insurance. ${ }^{4}$ Proposals which were previously contraindicated by the tenets of official ideology now commanded support from the medical employees' union as offering the only road out of an impasse created by the discredited Communist regime. Whether the strike threat had a catalytic effect on government or not, early in February Meditsinskaya Gazeta carried the text of the long awaited draft law (box).

\section{Months of delay}

Although the proposed reform had now seen the light of day, there were fears that it would be stifled at birth. According to one article, the scheme could work only on the basis of an annual expenditure of 224 roubles per person; the republican government budget allowed for a mere 115 roubles per person so that the

\section{Some cardinal principles of draft law on Russian health service reforms}

- A guaranteed amount of medical care free at time of consumption to all citizens

- Contributions to the compulsory insurance scheme by industrial and commerical enterprises for employed persons (that is, a sort of payroll tax)

- The government budget to make contributions through the town (or district) Soviet for the nonworking population

- Self-employed workers to be responsible for their own contributions

- Decentralised insurance funds to be set up

- The right to voluntary medical insurance for services in addition to what is guaranteed

- The right of free choice of doctor and health care unit.

total shortfall was 12 billion roubles. As for persuading the finance ministry to find more from general revenues, the medical deputies seemed simply not to have sufficient political clout. A sense of frustration was conveyed by $\operatorname{Dr}$ A A Askalonov, chairman of the committee for health protection, social security, and physical culture, in what sounds like a calculated understatement: "In the government," he said, "there is a lack of understanding about the significance of the needs of health care. ${ }^{15}$

Whether the financial obstacles were soon overcome is not clear, but overt political opposition certainly caused delay in enacting the draft law. At its first reading in the Russian parliament the draft encountered so much hostile comment or condemnation that those responsible for its passage adopted the tactical device of redesignating the session as a non-commital "presentation." As for the nature of the objections, some sound like formulations which derive from the previous official ideology. Thus, according to one source, many deputies were described as being "afraid of 'a rejection of ideals,' 'a retreat from the gains of socialism,' and 'a disregard of the workers' interests'."'6

In looking beyond the parliamentary context it does not strain credulity to suggest that hostility to this reform - as to other reforms - sometimes arose from a desire to preserve the status quo for simple reasons of self interest. That observation applies more particularly to incompetent doctors in practice and to medical bureaucrats hoping for preferment or an undemanding post in the existing overadministered system. Such people can perceive at least two major institutional changes as entailing a most unwelcome "leap in the dark." The first is that, with the introduction of "insurance medicine," the state monopoly on health care provision will end; units will be in various forms of ownership; and health departments, no longer responsible for allocating finance, will have to shed staff. The second and related point is that as the new independent insurance companies will be free to conclude such contracts as they consider are in their clients' best interests, to put the point crudely, bad doctors will lose out to caring and well qualified doctors.

However, opposition to the draft law had a somewhat Canute-like character, given that patients and doctors were deserting the state health service in droves. That is the only possible inference to draw from the evidence given in the source. Referring to the rapid growth in the black market for medical services, it said: "According to the estimates of one economist, its extent is seven to ten times greater than the extent of legally provided feecharging care." What made this flight from the state service so objectionable was that it occurred to a large extent within state provided units. Only 
the arrangements envisaged by the draft law could effectively force "moonlighting" (more accurately "daylighting") into a separately identifiable and independent subsystem.

\section{Vote in favour}

With the need to enact the draft law becoming more urgent as each day passed, its sponsors showed that they had learnt how to succeed in the rough and tumble of parliamentary democracy. In a heated debate they not only argued the case but also, apparently, showed flexibility by accepting several amendments. They were rewarded by an overwhelming vote. For the record, the main opponents spoke for the Federation of Independent Trade Unions of Russia; their criticisms turned on considerations of social justice.

As Meditsinskaya Gazeta saw the matter, the vote was a victory for the committee chaired by $\mathrm{Dr}$ Askalonov, and consequently it devoted some column inches to his comments. These are remarkable for the absence of what is often identified as a failing of the Russian intelligentsia-namely, the tendency to assume that a theoretically consistent scheme can be made to work well in practice. By contrast, $\mathrm{Dr}$ Askalonov did not claim that insurance medicine will provide the cure for all ills. He recognised that its introduction, by 1993 , must be preceded not only by the creation of the appropriate infrastructure but also by a public information programme, mention of which may be evidence of far more than concern with practical details: it may be held to flow from his acceptance that the scheme can only work well if it gains "social acceptabilfty."

Fairly self evidently, the general public are more likely to have positive attitudes towards "insurance medicine" if they experience a clear improvement in the quality of care provided by the rank and file of Russian doctors. And in this connection it is reasonable to conclude that under the new scheme consumer choice and the forces of the market place should turn out to be powerful incentives for professional self improvement.

1 Bliev Yu. (Besedoval) Kto est kto: Vyacheslav Ivanovich Kalinin, minist zdravookhraneniya RSFSR. Meditsinskaya Gazeta 1990 sentyabrya 23:2.

2 Borich I. Strakhovoi polis, vyruchai! Meditsinskaya Gazeta 1990 oktyabraya $28: 1$

3 Deputatskaya Gruppa Meditsinskikh Rabotnikov. Obrashchenie ko Vtorom S"ezdu narodnikh deputatov RSFSR. Meditsinshaya Gazeta 1990 dekabrya

4 Kuz'menko M, Kuznetsov A. Inovo net u nas puti. Meditsinskaya Gazeta 1991 yanvarya $11: 2$.

5 Kuzina N. Zakon rodilsya, no.... Meditsinskaya Gazeta 1991 fevralya 1:2.

6 Khudyakova T. Zdorov'e-dorozhe deneg. Izvestiya 1991 iyunya 11:3.

7 Kuzina N. Vybor sdelan. Meditsinskaya Gazeta 1991 iyunya 28: 2.

(Accepted 25 September 1991

\section{Medicine in Europe}

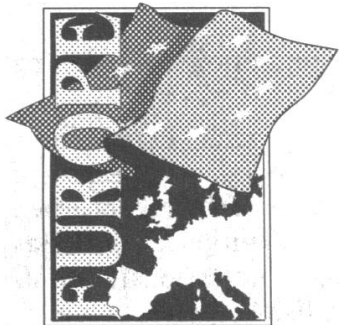

This is the sixth of a series of articles looking at medical issues in Europe.
British Medical Journal, London WC1H 9JR

Tessa Richards, MRCP, associate editor

BMF 1992;304:103-6

\section{Who speaks for whom?}

\section{Tessa Richards}

British doctors are waking up to Europe with a vengeance. Interest has been fuelled by many factors: the broadening and deepening of the European Community; the single market ${ }^{1}$; the oversupply of doctors and wide discrepancies in standards of training $^{2}$; trends in medical migration ${ }^{3}$; and patients crossing borders for treatment. The list goes on, but for whatever reasons all sections of the medical profession have set up European committees and are setting about influencing Brussels.

Those very few doctors who have been concerned with European medical affairs for decades have been cynically shaking their heads about this new found enthusiasm, but arguably it is a healthy sign. With the myriad of challenges and opportunities that the changing shape of Europe will bring there has never been a more important time for doctors to be aware of what is going on in the European Community.

The long established European medical bodies have been working for years, but new converts to Europe are concerned that they lack influence. The number of draft directives affecting health that have emerged after little discussion with doctors supports this view. The profession's voice has barely been heard among the cacophony of lobby groups in Brussels. Why this should be is unclear. Some are convinced that it is because the profession has lacked a substantive base in Brussels. Others cite personal and organisational factors. This article addresses these questions by taking a critical look at the bodies that represent or are seeking to represent doctors in Europe.

\section{Standing Committee of Doctors of the EC-An organisation at war with itself?}

Established in 1959 the standing committee or comité permanent (CP), which is an independent voluntary organisation, is the only body that claims to represent all doctors in all member states of the EC. It is the last common path to the European Commission for statements which it and other medical groups, who send liaison officers to its meetings, formulate. This puts it in a unique position of power and responsibility (figure).

Membership is large-each of the 12 member states send several delegates from their representative medical organisations. Numbers are swelled by observers from Austria, Switzerland, Finland, Cyprus, and Hungary. The British contingent is represented by the British Medical Association and consists of (by accident rather than by design) an occupational physician, a gynaecologist, a general practitioner, a public health physician, and a junior doctor, supported by members of the BMA's European division.

Costs are borne by the various medical associations, with each member state paying a weighted proportion The BMA's share is $17 \%$, which in 1991 amounted to about $£ 60000$; simultaneous translations at meetings, mountains of paperwork, maintaining a secretariat, travel and accommodation expenses, and generous entertainment do not come cheap.

The standing committee's aims are to represent the medical profession of all member states; study and promote high standards of medical practice and health care; and promote free movement of doctors. As evidence of its success in meeting these objectives it can cite its role in shaping the original doctors' directives on mutual recognition of diplomas and the directives on vocational training in general practice. It can also point to numerous impressive sounding charters, statements, and recommendations that it has sent to the commission on subjects ranging from patients' right to choose their own doctor to the ethical obligations of professionals to keep up to date. 